\title{
Analisis Kinerja Sistem Televisi Digital Didasarkan pada Standar International Telecomunication Union
}

\author{
Jauhariyatul Fajriyah"), Hudiono Hudiono ${ }^{2)}$, Nugroho Suharto ${ }^{3)}$ \\ ${ }_{1,2}$ Program Studi Jaringan Telekomunikasi Digital, \\ ${ }^{3}$ Program Studi Teknik Telekomunikasi, \\ Jurusan Teknik Elektro, Politeknik Negeri Malang, Indonesia \\ 1 jauhariyatulfajriyah@gmail.com, ${ }^{2}$ hudiono@polinema.ac.id, ${ }^{3}$ nugroho.suharto@polinema.ac.id
}

\begin{abstract}
This study aims to determine the effect of the selection of the DVB-T2 parameter value on system performance. The parameters used are the parameters of Bandwidth, FFT size, Guard Interval, and Modulation Technique. The parameter values ??used are in accordance with those recommended by the ITU. System performance is observed by performing calculations and simulations. The simulation is carried out with the help of MATLAB software. The results of the simulation are observed with BER and SNR values ??to see the effect of fft size, Guard Interval and modulation techniques, while the effect of bandwidth values ??is observed by performing calculations. The results obtained show that the $10 \mathrm{MHz}$ bandwidth has the largest channel capacity value with an increase of $25 \%$ from the $8 \mathrm{MHz}$ bandwidth value. Simulations carried out at the FFT size show that it does not have much effect on the performance of the DVBT2 system. In the simulation, the Guard Interval value shows that the use of the Guard Interval value does not really affect the BER and SNR values, while the calculation of the effect of the Guard Interval on the maximum transmission distance in SFN mode shows that the maximum distance is generated with a Guard Interval value of 19/128 with an FFT value of $32 \mathrm{~K}$. with a distance of $159.5 \mathrm{Km}$. In the simulation of the modulation technique, the results show that QPSK has the best BER resistance compared to other modulation techniques, this is also in line with the results of the calculations.
\end{abstract}

Keywords-DVB-T2, bandwidth, fft size, guard interval, modulation technique

Abstrak - Penelitian ini bertujuan untuk mengetahui tentang pengaruh pemilihan dari nilai parameter DVB-T2 terhadap kinerja sistem. Parameter yang digunakan untuk yaitu parameter Bandwidth, FFT size, Guard Interval, dan Teknik Modulasi. Nilai parameter yang digunakan sesuai dengan yang direkomendasikan oleh ITU. Unjuk kerja sistem diamati dengan melakukan perhitungan dan simulasi. Simulasi dilakukan dengan bantuan software MATLAB. Hasil pada simulasi diamati dengan nilai BER dan SNR untuk melihat pengaruh dari ukuran fft, Guard Interval dan teknik modulasi, sedangkan untuk pengaruh nilai bandwidth diamati dengan melakukan perhitungan. Hasil yang didapatkan menunjukkan bandwidth 10 MHz memiliki nilai kapasitas kanal yang paling besar dengan kenaikan sebesar $25 \%$ dari nilai bandwidth 8 MHz. Simulasi yang dilakukan pada ukuran FFT menunjukkan tidak banyak berpengaruh terhadap performansi sistem DVB-T2. Pada simulasi nilai Guard Interval menunjukkan, bahwa penggunaan nilai Guard Interval tidak terlalu berpengaruh terhadap nilai BER dan SNR, sedangkan perhitungan pengaruh Guard Interval terhadap jarak maksimum transmisi dalam mode SFN didaptkan jarak maksimum dihasilkan dengan nilai Guard Interval sebesar 19/128 dengan nilai FFT sebesar 32K dengan jarak $159.5 \mathrm{Km}$. Pada simulasi teknik modulasi, didapatkan hasil bahwa QPSK memiliki ketahanan BER yang paling baik daripada teknik modulasi yang lain, hal ini juga sejalan dengan hasil perhitungan yang dilakukan.

Kata kunci-DVB-T2, bandwidth, fft size, guard interval, teknik modulasi

\section{PENDAHULUAN}

Televisi digital adalah jenis televisi yang menggunakan modulasi digital dan sistem kompresi untuk menyiarkan sinyal gambar, suara, dan data ke pesawat televisi. Terdapat beberapa standar sistem pemancar televisi digital di dunia, di antaranya yaitu televisi digital (DTV) di Amerika, penyiaran video digital terestrial (DVB-T) di Eropa, dan layanan penyiaran digital terestrial terintegrasi (ISDB-T) di Jepang. Di Indonesia penyiaran TV digital menggunakan standart DVB-T2 sesuai dengan Peraturan Menteri Nomor: 05/PER/M.KOMINFO/2/2012.

Digital Video Broadcasting - Second Generation Terrestrial (DVB-T2) merupakan standar teknologi penyiaran televisi digital terestrial yang di publikasikan oleh European Telecommunications Standards Institute (ETSI) pada bulan September 2009. Dibandingkan dengan DVB-T, standar DVB-
T2 menawarkan lebih banyak pilihan parameter OFDM dan skema modulasi.

Untuk mengetahui bagaimana kinerja system penyiaran televisi digital maka perlu dilakukan analisis terhadap kinerja system penyiaran televisi digital yang di dasarkan pada standart International Telecomunication Union (ITU). Dalam penelitian ini akan membahas pengaruh dari parameter DVB-T2 terhadap kinerja system, di antaranya parameter Bandwidth, FFT size, Guard Interval, dan Teknik Modulasi sesuai dengan yang telah direkomendasikan oleh International Telecomunication Union (ITU).

International Telecommunication Union (ITU) merupakan sebuah organisasi internasional yang didirikan untuk membakukan dan meregulasi radio internasional. Tujuan utamanya meliputi standardisasi, pengalokasian spektrum radio, dan mengorganisasikan perjanjian rangkaian 
interkoneksi antara negara-negara berbeda untuk memungkinkan panggilan telepon internasional.

ITU membawahi tiga bidang yang mempunyai kedudukan sederajad yaitu: Radio Communication Conference (yang ditangani oleh ITU-R: ITU sektor radio), Telecommunication Conference (yang ditangani oleh ITU-T: ITU sektor telekomunikasi) dan Telecommunication Development Communications Conference (yang ditangani oleh ITU-D: ITU sektor development). Produk dari ITU-R adalah regulasi berbentuk rekomendasi dalam bidang radio dan spectrum frekuensi internasional, yang diberi nomor seri angka [10].

Digital Video Broadcasting - Second Generation Terrestrial (DVB-T2) merupakan standar teknologi penyiaran televisi digital terestrial yang dipublikasikan oleh European Telecommunications Standards Institute (ETSI) pada bulan September 2009. Teknologi generasi kedua dari DVB -T ini mengembangkan fasilitas dan fitur baru serta memperkenalkan modulasi dan teknik coding yang memungkinkan penggunaan spektrum frekuensi secara efisien untuk pengiriman layanan audio, video maupun data. International Telecommunication Union dalam Report ITU-R BT.2254-3 (03/2017) Frequency and network planning aspects of DVB-T2, menjelaskan bahwa DVB-T2 memiliki beberapa pengembangan dari generasi sebelumnya.

Pada physical layer, pemancar DVB-T2 yang lengkap memproses data biner dan sinyal output domain waktu ke frekuensi radio (RF) melalui modul transmisi sirkuit. Gambar 1 menunjukkan diagram blok high level dari sistem DVB-T2.

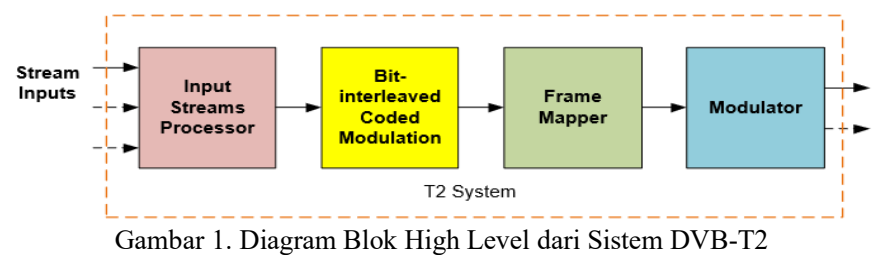

Dalam rekomendasi ITU-R BT.2468-0 menjelaskan tentang panduan dalam memilih parameter sistem dalam mengimplementasikan sistem DVB-T2. Dalam rekomendasi tersebut menjelaskan dalam menentukan nilai parameter yang digunakan, ITU sudah menetapkan perihal besar nilai parameter dalam ITU-R BT.1877-2 hanya saja dalam pemilihan nilai dalam implementasinya membutuhkan banyak pertimbangan. Dalam rekomendasi tersebut dijelaskan bahwa dalam pemilihan parameter untuk generasi kedua dari dvb-t ini dapat dipilih secara benar untuk beberapa keadaan seperti :

a) Mempertahankan cakupan yang sama;

b) Meningkatkan cakupan;

c) Mempertahankan bit rate data yang sama dalam saluran 6/7/8 mhz;

d) Meningkatkan bit rate data dalam saluran $6 / 7 / 8 \mathrm{mhz}$;

e) Mendapatkan mode dengan kekuatan yang lebih besar untuk gangguan;

f) Mengevaluasi mode dengan ketahanan yang kurang terhadap gangguan sementara ditingkatkan dengan fitur lain; dan

g) Mempertimbangkan konsekuensi kepada khalayak penerima karakteristik yang akan dipilih.
Untuk pemilihan nilai parameter yang ditetapkan oleh kominfo juga dijelaskan dalam peraturan nomor 9 tahun 2014 beberapa rekomendasi tersebut yaitu :

a) Modulasi : OFDM

b) Channel Bandwidth: $8 \mathrm{MHz}$

c) Transmission Mode: $1 \mathrm{~K}, 2 \mathrm{~K}, 4 \mathrm{~K}, 8 \mathrm{~K}, 16 \mathrm{~K}, 32 \mathrm{~K}$

d) Guard Interval: 1/4, 19/256, 1/8, 19/128,1/16,1/32,1/128

e) Forward Error Correction (FEC) : 1/2, 3/5, 2/3, 3/4, 4/5, 5/6

f) Konstelasi: QPSK, 16 QAM, 64 QAM, 256 QAM

g) Video Decoding

h) Video Decoder :MPEG-4 AVC (H.264)

i) Video Aspect Ratio: $4: 3 ; 16: 9$

j) Resolution Source Video : SDTV 720 × 576 , HDTV 1920/1080i, HDTV 1920/1080p (optional)

\section{METODE}

\section{A. Perancangan Simulasi}

Pada penelitian ini simulasi dirancang dengan menggunakan MATLAB R2015a. Program simulasi ini merupakan pemodelan dari sistem OFDM yang digunakan pada sistem DVB-T2 dimana setiap besaran parameter sesuai dengan yang direkomendasikan oleh ITU. Tujuan akhir dari pembuatan program simulasi matlab ini untuk mengetahui pengaruh penggunaan kombinasi dari penggunaan nilai bandwidth, fft size, guard interval serta penggunaan teknik modulasi terhadap performansi sistem dvb-t2. Dalam perancangan sistem ini hasil akan diamati dengan grafik nilai BER terhadap SNR. Diagram alir tahap perancangan simulasi ditunjukkan oleh gambar 2.

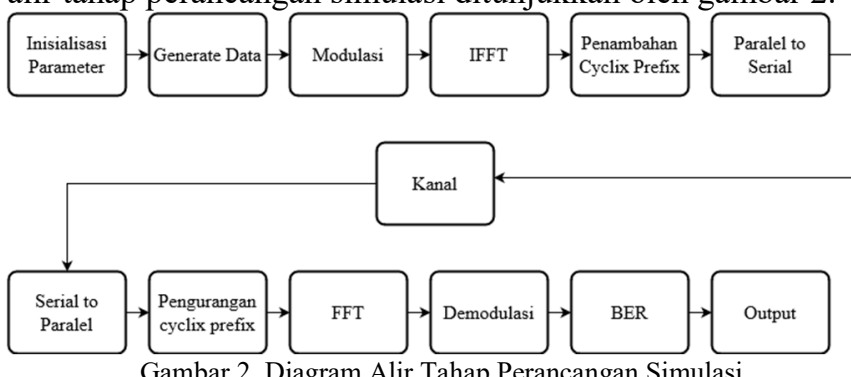

\section{B. Perhitungan Parameter Sistem DVB-T2}

\section{1) Pengaruh Bandwidth Terhadap Kapasitas Kanal}

Setelah mengetahui besar bandwidth sinyal yang digunakan untuk tiap nilai bandwidth kanal maka pemanfaatan terhadap bandwidth kanal ini tentu memiliki hubungan erat dengan kapasitas kanal yang dimiliki oleh DVB-T2. DVB-T2 memiliki kinerja sistem yang sangat dekat dengan Shannon Limits, dimana Shannon Limits ini mendefinisikan batas efisiensi untuk komunikasi digital [19]. Dalam teori informasi, teorema Shannon-Hartley memberi tahu tingkat maksimum di mana informasi dapat ditransmisikan melalui saluran komunikasi dari bandwidth tertentu di hadapan kebisingan.

Persamaan Shannon dalam bit per detik:

Keterangan :

$$
C=W \log 2\left(1+\frac{P}{N}\right)
$$

$\mathrm{C}:$ kapasitas kanal (bit/s)

W : bandwidth $(\mathrm{Hz})$ 
$\mathrm{P} / \mathrm{N}$ : signal to noise ratio $(\mathrm{S} / \mathrm{N})$

Dengan persamaan diatas nilai bandwidth kanal untuk sistem DVB-T2 akan di analisis terhadap pengaruhnya kepada nilai kapasitas kanal. Kapasitas kanal adalah banyaknya informasi yang bisa dilewatkan dalam sebuah kanal transmisi, mempunyai satuan bit per detik. Semakin besar nilai kapasitas kanal semakin banyak informasi yang dapat dilewatkan dalam sebuah kanal transmisi, menghasilkan tingkat quality of service yang semakin baik.

\section{2) Pengaruh Guard Interval Terhadap Jarak Maksimum Transmisi}

Pada implementasinya Guard Interval juga berpengaruh terhadap jarak jangkau dalam sistem jaringan SFN (Single Frequency Network). Single Frequency Network merupakan jaringan penyiaran dimana beberapa pemancar mengirimkan sinyal yang sama secara simultan, dalam frekuensi yang sama dan dalam waktu yang sama. Untuk SFN (jaringan frekuensi tunggal) kita dapat menghitung jarak antara pemancar atau antara sinyal langsung dan multipath dengan menggunakan guard interval dan mode ukuran FFT.

Persamaan yang bisa digunakan untuk mengetahui jarak maksimum antara transmitter yaitu :

$$
\text { Carrier spacing }(c s)=\frac{\text { Bandwidth Signal } \mathrm{Hz}}{\text { Number of carriers }}
$$

Total Symbol Duration $($ Tu $)=1 /$ carrier spacing $($ cs)

Guard interval in micro seconds $(G i \mu s)=T u \times G i$

Jarak $=$ Guard interval $\times$ Velocity of light $(V o)$

3) Pengaruh Teknik Modulasi terhadap Nilai Probabilitas $B E R$

Persamaan nilai BER untuk teknik modulasi QPSK pada kanal AWGN adalah:

$$
B E R_{Q P S K}=\frac{1}{2} \operatorname{erfc}(\sqrt{E b / N o})[23]
$$

Persamaan nilai BER untuk teknik modulasi 16-QAM pada kanal AWGN adalah :

$$
B E R_{16 Q A M}=\frac{3}{8} \operatorname{erfc}\left(\sqrt{\frac{2}{5} E b / N o}\right)-\frac{9}{64}(e r f c)^{2}\left(\sqrt{\frac{2}{5} E b / N o}\right)
$$

Persamaan nilai BER untuk teknik modulasi 64-QAM pada kanal AWGN adalah :

$$
\begin{aligned}
B E R_{64 Q A M}=7 / 24 & \operatorname{erfc}(\sqrt{ }(1 / 7 \mathrm{~Eb} / \mathrm{No})) \\
& -49 / 384(\operatorname{erfc})^{2}\left(\sqrt{\frac{1}{7} E b / N o}\right)
\end{aligned}
$$

Persamaan nilai BER untuk teknik modulasi 256-QAM pada kanal AWGN adalah :

$$
\begin{aligned}
B E R_{256 Q A M}=\frac{15}{64} & \operatorname{erfc}\left(\sqrt{\frac{5}{85} E b / N o}\right) \\
& -\frac{225}{2048}(\operatorname{erfc})^{2}\left(\sqrt{\frac{4}{85} E b / N o}\right)
\end{aligned}
$$

\section{HASIL DAN PEMBAHASAN}

\section{A. Perhitungan Pengaruh Bandwidth Terhadap Kapasitas Kanal}

Pengujian ini bertujuan untuk mengetahui pengaruh dari penggunaan masing-masing nilai bandwidth terhadap kapasitas kanal. Dalam DVB-T2 bandwidth kanal memiliki 6 rekomendasi yang diberikan oleh ITU yaitu $1.7 \mathrm{MHz}, 5 \mathrm{MHz}$, $6 \mathrm{MHz}, 7 \mathrm{MHz}, 8 \mathrm{MHz}$, dan $10 \mathrm{MHz}$. Pengujian dilakukan dengan melakukan perhitungan dengan mengimplementasikan teori Shannon tentang kapasitas kanal. Hasil yang didapatkan adalah :

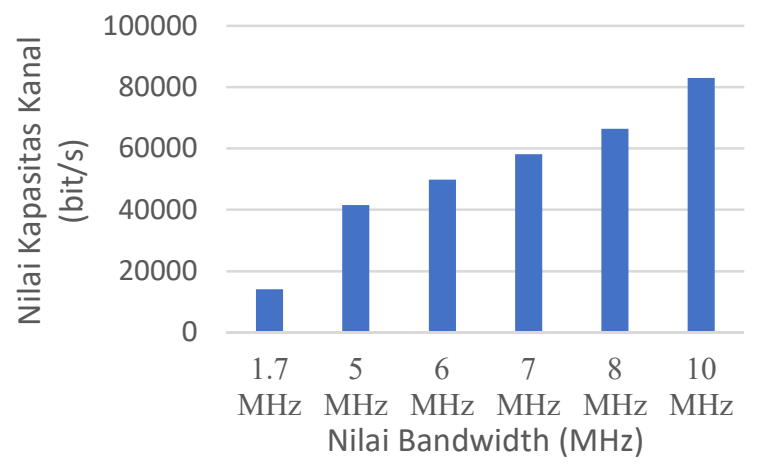

Gambar 3. Grafik Pengaruh Nilai Bandwidth terhadap Kapasitas Kanal

Berdasarkan pada grafik dari hasil perhitungan diatas maka akan semakin terlihat bahwa hasil perhitungan untuk masingmasing nilai bandwidth dan pengaruhnya terhadap kapasitas kanal. Berdasarkan hasil perhitungan diatas maka didapatkan nilai kapasitas kanal terbesar pada nilai bandwidth sebesar 10 $\mathrm{MHz}$ dengan hasil 83000 bit/s. Secara umum, semakin besar bandwidth sinyal, semakin tinggi kapasitas pembawa informasi, tetapi kemampuan sistem transmisi dan penerima membatasi bandwidth yang dapat ditransmisikan. Karenanya kecepatan data tergantung pada bandwidth yang tersedia untuk transmisi, kapasitas saluran dan rasio signal-to-noise, serta kemampuan penerima.

\section{B. Simulasi Ukuran FFT Terhadap Nilai BER dan SNR}

Untuk melakukan simulasi serta menampilkan hasil yang didapatkan untuk mengetahui pengaruh dari perbedaan penggunaan ukuran FFT terhadap nilai BER dan SNR. Simulasi ini dilakukan dengan mengganti nilai subscarrier yang akan diimplementasikan pada simulasi sesuai dengan ukuran subscarrier yang sudah ditentukan oleh ITUR.BT.2254-3 untuk tiap ukuran fft dengan menggunakan variasi bandwidth $8 \mathrm{MHz}$, teknik modulasi 16-QAM dan guard interval sebesar 1/4. Input data yang digunakan merupakan generate data random seperti yang sudah dijelaskan pada bab 2 . Setalah menginputkan parameter yang dibutuhkan untuk proses simulasi maka hasil yang didapatkan sebagai berikut : 


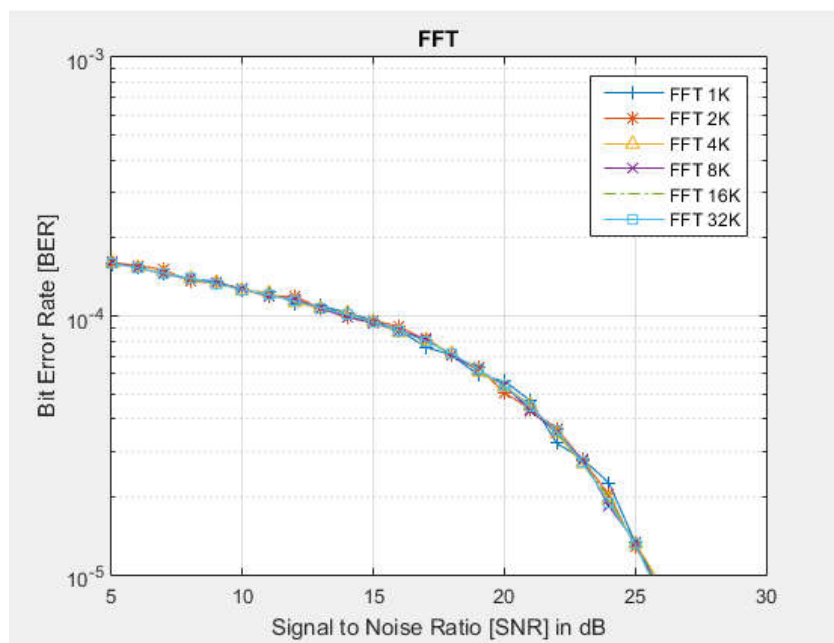

Gambar 4. Grafik Pengaruh FFT terhadap BER dan SNR

Dari hasil simulasi yang ditampilkan pada grafik diatas dapat diketahui bahwa untuk tiap ukuran FFT baik 1K, 2K, 4K, $8 \mathrm{~K}, 16 \mathrm{~K}$ maupun $32 \mathrm{~K}$ memiliki hasil yang tidak jauh berbeda untuk nilai BER terhadap SNR. Hal ini dapat dilihat dari hasil untuk tiap ukuran yang rata-rata memiliki nilai BER yang sama untuk tiap SNR nya. Terlihat nilai BER semakin membaik pada SNR sekitar $23 \mathrm{~dB}$. Hal ini disebabkan karena variasi jumlah subcarrier tidak berpengaruh pada sistem. Variasi jumlah subcarrier hanya berpengaruh dalam membagi sejumlah data yang panjang dengan kecepatan tinggi menjadi paket-paket data yang lebih kecil dengan kecepatan yang lebih rendah pula namun tidak berpengaruh pada unjuk kerja sistem.

\section{Performansi Guard Interval}

\section{1) Pengaruh Guard Interval Terhadap Durasi Simbol OFDM}

Persamaan yang digunakan merupakan persamaan yang mengacu pada bab 2. Perhitungan dilakukan dengan menggunakan parameter ukuran $\mathrm{fft}$ sebesar $16 \mathrm{~K}$ pada bandwidth $8 \mathrm{MHz}$ dengan nilai Tu sebesar 1,792 ms. Hasil yang didapat dapat dilihat pada grafik dibawah ini :

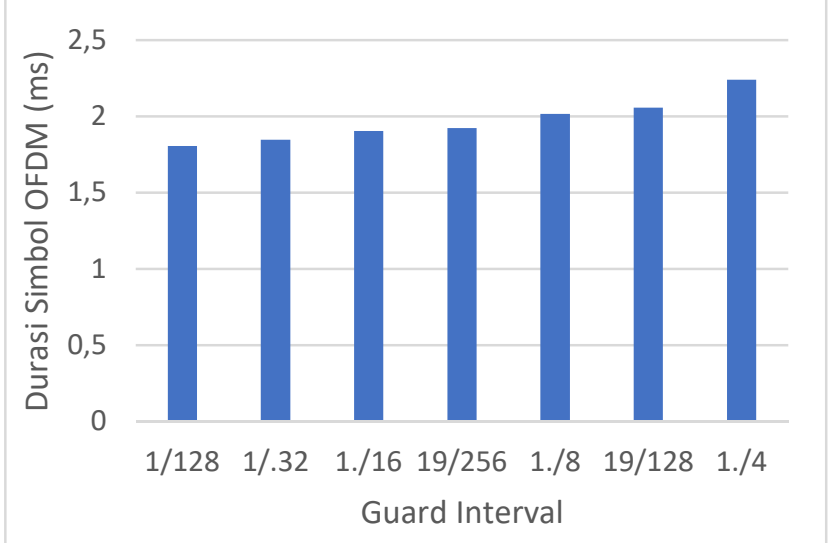

Gambar 5. Grafik Pengaruh Nilai Guard Interval terhadap Durasi Simbol OFDM

Pada grafik diatas didapatkan hasil pada FFT size sebesar $16 \mathrm{~K}$ dengan bandwidth sebesar $8 \mathrm{MHz}$ bahwa durasi atau periode symbol OFDM akan semakin panjang tiap kenaikan nilai guard interval, yang berarti waktu yang dibutuhkan juga semakin lama dengan semakin meningkatnya nilai guard interval yang digunakan. Namun perbedaan durasi yang terjadi antar tiap nilai guard interval terhadap nilai durasi total symbol OFDM tidak terlalu signifikan hanya sebesar $1 \%-8 \%$ untuk masing-masing kenaikan periode total symbol.

2) Perhitungan Guard Interval Terhadap Jarak Maksimum Transmisi

Pada perhitungan ini dipilih nilai bandwidth sebesar $8 \mathrm{MHz}$ dengan ukuran fft sebesar $8 \mathrm{~K}$. Jika dilihat dari pengaruhnya terhadap jarak maksimum transmisi pada sistem jaringan SFN berdasarkan persamaan yang terdapat pada bab sebelumnya maka hasil yang di dapat yaitu :

TABEL I

HASIL PENGARUH GUARD INTERVAL TERHADAP JARAK MAKSIMUM TRANSMISI PADA JARINGAN SFN

\begin{tabular}{cccccccc}
\multicolumn{7}{c}{ MAKSIMUM TRANSMISI PADA JARINGAN SFN } \\
\hline \multirow{2}{*}{ FFT } & $1 / 128$ & $1 / 32$ & $1 / 16$ & $19 / 256$ & $1 / 8$ & $19 / 128$ & $1 / 4$ \\
\cline { 2 - 8 } $32 \mathrm{~K}$ & 8.4 & 33.6 & 67.2 & 79.8 & 134.4 & 159.5 & N/A \\
$16 \mathrm{~K}$ & 4.2 & 16.8 & 33.6 & 39.9 & 67.2 & 79.8 & 134.4 \\
$8 \mathrm{~K}$ & 2.1 & 8.4 & 16.8 & 19.9 & 33.6 & 39.9 & 67.2 \\
$4 \mathrm{~K}$ & N/A & 4.2 & 8.4 & N/A & 16.8 & N/A & 33.6 \\
$2 \mathrm{~K}$ & N/A & 2.1 & 4.2 & N/A & 8.4 & N/A & 16.8 \\
$1 \mathrm{~K}$ & N/A & N/A & 2.1 & N/A & 4.2 & N/A & 8.4 \\
\hline
\end{tabular}

Dilihat dari hasil perhitungan pada tabel diatas, maka dapat dilihat pada nilai bandwidth sebesar $8 \mathrm{MHz}$ bahwa nilai maksimum jarak yang didapat berdasarkan perubahan nilai Guard Interval dan perubahan nilai FFT sebesar $159.5 \mathrm{Km}$. Hasil ini didapatkan dari perpaduan nilai Guard Interval sebesar 19/128 dengan nilai FFT sebesar 32K, dimana kedua nilai masing masing merupakan nilai maksimum yang disediakan pada setiap parameter, baik guard interval maupun FFT. Hal ini menandakan bahwa semakin besarnya nilai guard interval yang digunakan dengan seiring semakin besarnya nilai FFT maka jarak yang bisa ditempuh oleh sistem DVB-T2 dalam sistem jaringan Single Frequency Network juga akan semakin besar.

\section{3) Simulasi Guard Interval pada Nilai BER dan SNR}

Pada simulasi dilakukan dengan melakukan variasi dengan menggunakan ukuran fft sebesar $16 \mathrm{~K}$ dan bandwidth sebesar 8 $\mathrm{MHz}$. Setalah menginputkan parameter yang dibutuhkan untuk proses simulasi maka hasil yang didapatkan sebegai berikut : 


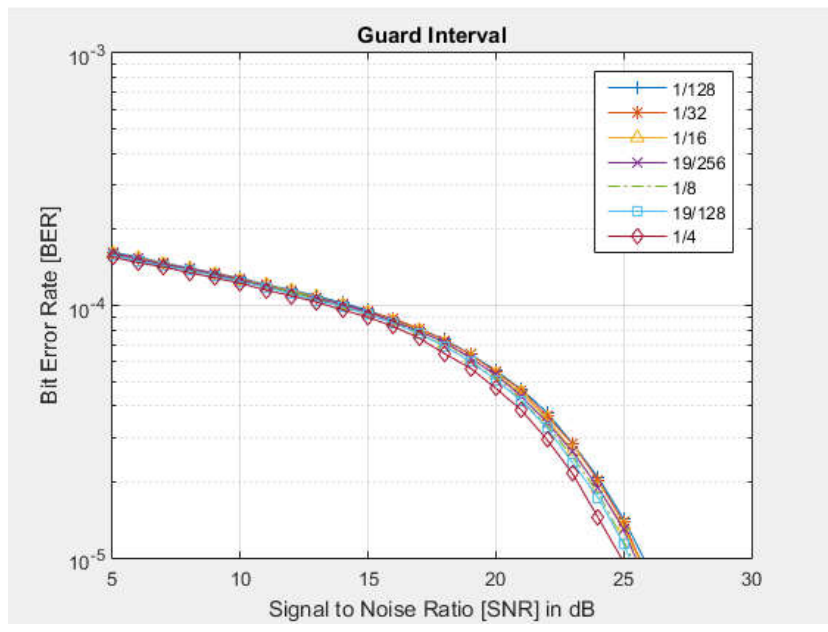

Gambar 6. Grafik Pengaruh Nilai Guard Interval terhadap BER dan SNR

Dari grafik diatas dapat dilihat perbedaan nilai BER terhadap SNR dari tiap nilai guard interval yang digunakan. Grafik memperlihatkan bahwa tiap nilai guard interval rata-rata memiliki hasil yang sama untuk nilai BER terhadap SNR. Dimana rata-rata pada setiap nilai guard interval akan menghasilkan kinerja yang akan membaik pada SNR sebesar $23 \mathrm{~dB}$ dengan rata-rata nilai BER sebesar $10^{-5}$. Hasil di atas menandakan bahwa nilai guard interval tidak terlalu berpengaruh terhadap performansi. Hal ini dikarenakan guard interval atau cyclic prefix pada OFDM yang berfungsi untuk mencegah terjadinya ISI dan ICI ternyata tidak begitu berpengaruh terhadap performansi atau kinerja dari DVB-T2 dikarenakan pada DVB-T2 menggunakan estimasi kanal walaupun dengan penggunaan estimasi kanal yang sederhana seperti linear interpolation.

\section{Performansi Teknik Modulasi}

\section{1) Perhitungan Teknik Modulasi Terhadap Probabilitas BER}

Perhitungan ini dilakukan untuk mengetahui pengaruh dari penggunaan teknik modulasi terhadap laju kesalahan bit (BER). Dengan melakukan perhitungan BER dengan persamaan yang ada pada bab 3. Untuk melakukan perhitungan dibawah ini, maka dibutuhkan nilai Eb/No dimana dalam hal ini akan diberikan nilai Eb/No sebesar 20dB. Hasil yang didapatkan yaitu

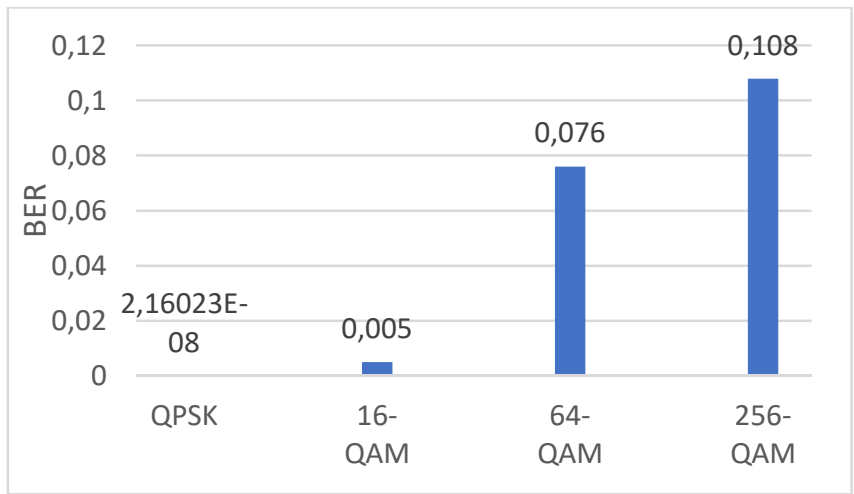

Gambar 7. Grafik Pengaruh Jenis Modulasi terhadap Nilai BER
Dari hasil perhitungan dalam grafik di atas dapat dilihat bahwa tiap teknik modulasi memiliki nilai berbeda terhadap hasil perhitungan BER. Terlihat bahwa Teknik Modulasi 256 QAM memiliki nilai probabilitas BER yang lebih tinggi dibandingkan dengan teknik modulasi yang lain. Grafik tersebut juga memeperlihatkan bahwa QPSK memiliki hasil yang paling bagus yakni nilai BER mendekati 0 .

2) Simulasi Teknik Modulasi Terhadap Nilai BER dan SNR

Simulasi dilakukan menggunakan parameter FFT size sebesar $1 \mathrm{~K}$ dan Guard Interval sebesar 1/4 untuk semua teknik modulasi. Hasil simulasi untuk tiap teknik modulasi dapat dilihat pada gambar hasil sebagai berikut :

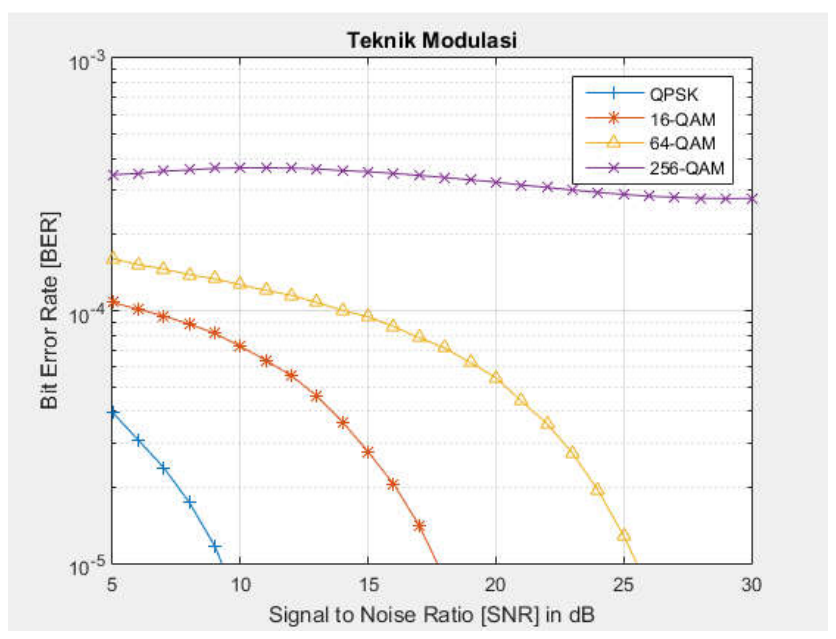

Gambar 8. Grafik Pengaruh Jenis Modulasi terhadap BER dan SNR

Dari grafik hasil simulasi diatas dapat diketahui pengaruh penggunaan tiap teknik modulasi terhadap nilai BER dibandingkan dengan SNR. Pada grafik terlihat kinerja teknik modulasi QPSK menghasilkan nilai BER sebesar $10^{-5}$ pada SNR sekitar 6,3 dB. Untuk 16-QAM mencapai BER sebesar $10^{-5}$ pada SNR sekitar $14,8 \mathrm{~dB}$, Sedangkan untuk 64 QAM dan 256 QAM membutuhkan SNR lebih dari $20 \mathrm{~dB}$ untuk bisa mencapai nilai BER sebesar $10^{-5}$. Hal ini menunjukkan bahwa teknik modulasi QPSK memiliki ketahanan yang paling baik daripada 16 QAM, dan 64 QAM. Hal ini menandakan semakin banyaknya bit yang mewakili simbol maka ketahanan terhadap deraunya menjadi semakin rendah. Pada teorinya QPSK hanya terdiri 2 bit dalam satu simbolnya, 16 QAM terdiri dari 4 bit, dan 64 QAM terdiri dari 8 bit dalam satu simbolnya.

\section{KESIMPULAN}

Parameter kinerja sistem televisi digital berdasarkan International Telecomunication Union (ITU) yaitu terdapat 28 parameter yang sudah dijelaskan dalam ITU-R BT.1877-2 dimana dalam penelitian ini dipilih 4 parameter yang akan diuji, yaitu bandwidth kanal, ukuran fft, guard interval dan teknik modulasi.

Berdasarkan perhitungan dan simulasi yang dilakukan pada masing - masing parameter didapatkan nilai bandwidth 10 $\mathrm{MHz}$ memiliki nilai kapasitas kanal yang paling besar dengan kenaikan sebesar $25 \%$ dari nilai bandwidth $8 \mathrm{MHz}$ yang merupakan nilai bandwidth kanal terbesar yang dimiliki DVB- 
T. Simulasi yang dilakukan pada ukuran FFT menunjukkan tidak banyak berpengaruh terhadap performansi sistem DVBT2 dilihat dari perolehan grafik nilai BER terhadap SNR yang dihasilkan. Perhitungan pengaruh guard interval terhadap durasi simbol OFDM didapatkan hasil bahwa nilai guard interval sebesar $1 / 4$ memiliki durasi yang paling lama dibandingkan dengan nilai guard interval yang lain, dan untuk perhitungan pengaruh guard interval terhadap jarak maksimum transmisi dalam mode SFN didaptkan jarak maksimum dihasilkan dengan nilai guard interval sebesar 19/128 dengan nilai FFT sebesar $32 \mathrm{~K}$ dengan jarak $159.5 \mathrm{Km}$, sedangkan untuk simulasi nilai guard interval menunjukkan, bahwa penggunaan nilai guard interval tidak terlalu berpengaruh terhadap nilai BER dan SNR. Pada simulasi pengujian teknik modulasi, didapatkan hasil bahwa QPSK memiliki ketahanan BER yang paling baik daripada teknik modulasi yang lain, hal ini juga dibuktikan dengan perhitungan yang dilakukan untuk mengetahui nilai BER dari masing-masing teknik modulasi.

Berdasarkan peraturan KOMINFO nomor 3 tahun 2019 bahwa penggunaan nilai bandwidth yang dianjurkan yaitu sebesar $8 \mathrm{MHz}$, dengan nilai FFT size sebesar 32K, guard interval sebesar 1/16 dan penggunaan teknik modulasi sebesar 64-QAM. Hanya saja parameter teknis tersebut dapat dilakukan perubahan sesuai dengan kebutuhan pasar dan kondisi wilayah tertentu dengan persetujuan Direktur Jenderal yang menangani urusan Sumber Daya dan Perangkat Pos dan Informatika sesuai ketentuan peraturan perundang- undangan.

\section{REFERENSI}

[1] D. Arisetyanti and G. Hendrantoro, "Optimasi Single Frequency Network pada Layanan TV Digital DVB-T dengan Menggunakan Metode Simulated Annealing," vol. $1,2012$.

[2] Budiarto Hary, TV Digital. 2007.

[3] KOMINFO, "Peraturan Menteri Komunikasi Dan Informatika Republik Indonesia Nomor 6 Tahun 2019 Tentang Rencana Induk Frekuensi Radio Untuk Keperluan Penyelenggaraan Televisi Siaran Digital Terestrial Pada Pita Frekuensi Radio Ultra High Frequency," vol. 53, no. 9, pp. 1689-1699, 2019.

[4] International Telecommunication Union, "Report ITU-R BT.2254-3 (03/2017) Frequency and network planning aspects of DVB-T2 BT Series Broadcasting service," Geneva, vol. 2254, 2017.

[5] S. Nattapan, S. Promwong, and M. Chamchoy, "Evaluation of DVB-T2 transmission channel in Bangkok, Thailand," 2nd Jt. Int. Conf. Digit. Arts, Media Technol. 2017 Digit. Econ. Sustain. Growth, ICDAMT 2017, pp. 79-84, 2017.

[6] S. Budi, R. Hidayat, I. W. Mustika, and S. Sunarno, "Identifikasi Pengaruh Lintasan-Jamak pada DVB-T2 Berdasar Uji Penerimaan Siaran,” J. Nas. Tek. Elektro dan Teknol. Inf., vol. 5, no. 2, 2016.

[7] M. Sania Asri, "Implementasi Dan Analisis Pengaruh Ukuran OFDM Pada DVB- T2 Berbasis Software Gnuradio Implementation and Analysis Effect Of FFT
Size OFDM System On DVb-T2 Based Gnuradio Software," vol. 5, no. 3, pp. 4966-4972, 2018.

[8] G. Martínez, J. Sánchez, D. Barquero, and N. Cardona, "Optimization of the Digital Terrestrial Television Transmission Mode of DVB-T2 in Colombia," IEEE Lat. Am. Trans., vol. 13, no. 7, pp. 2144-2151, 2015.

[9] N. Nezya and Endroyono, "Analisa Sistem DVB-T2 di Lingkungan Hujan Tropis," vol. 1, no. 1, 2014, pp. 1-5.

[10] S. Haryadi, "Ikhtisar Organisasi Regulasi Telekomunikasi," 2018.

[11] International Telecommunication Union, "Errorcorrection, data framing, modulation and emission methods for second generation of digital terrestrial television broadcasting systems BT Series Broadcasting service," vol. 1877, 2019.

[12] International Telecomunicattion Union, "Guidance for selection of system parameters and implementation of second generation DTTB systems BT Series Broadcasting service," 2019.

[13]T. W. Kusuma, "SISTEM SIARAN DIGITAL VIDEO BROADCASTING TERESTRIAL 2 (DVB-T2) DI SCTV BATAM," Phys. Rev. E, vol. 2, p. 53, 2011.

[14] Institute of Electrical and Electronics Engineers, "IEEE Standard Glossary of Software Engineering Terminology," Office, vol. 121990, no. 1, p. 1, 1990.

[15]Kominfo, "Peraturan Menteri KOMINFO RI Nomor 3 Tahun 2019," 2019.

[16]D. Terrestrial and T. Action, Understanding DVB-T2 Key technical, business, \& regulatory implications. Geneva, Switzerland: Digital Terrestrial Television Action Group, 2009.

[17] A. A. W. ABOBAKER, "Study and Simulation of Dvb-T2 Ird Performance for Different Types of Channels," no. June, pp. 161-170, 2000.

[18]M. YU, "A Study of DVB-T2 Standard with Physical Layer Transceiver Design and Implementation," 2011.

[19]ETSI, "Digital Video Broadcasting (DVB); Frame structure channel coding and modulation for a second generation digital terrestrial television broadcasting system (DVB-T2)," Intellect. Prop., vol. 1, pp. 1-189, 2015.

[20]K. Syahgustina, "Simulasi Dan Analisa Kinerja Sistem Mimo Ofdm-Fdma Simulasi Dan Analisa Kinerja Sistem Mimo Ofdm-Fdma," 2009.

[21]G. J. Herianto, “Analisa Performansi Teknik Channel Coding Dan Decoding Menggunakan Convolutional Code Dan Algoritma Viterbi," 2011.

[22] A. P. Galih, "Design and Realization Software Monitoring System At Digital Television Dvb-T2," Sepuluh Nopember Institute of Technology, 2015.

[23] T. Arfianto, "Optimasi Parameter Transmisi OFDM pada DVB-T untuk Penerimaan Tetap dan Bergerak," J. Telekomun. dan Komput., vol. 3, no. 2, p. 113, 2017.

[24]W. Fischer, Digital Video and Audio Broadcasting Technology.

[25]H. K. Anjani, R. P. Astuti, and Y. S. Rohmah, "Analisis Mode Penerimaan Fixed ( Roof-Top ) Pada Performansi 
Pemancar Televisi Digital ( Dvb-T2 ) Dalam Single Frequency Network ( Sfn )," Anal. Mode Penerimaan Fixed Pada Performansi Pemancar Telev. Digit. Dalam Single Freq. Netw., vol. 1, no. 1, pp. 89-96, 2014.

[26] R. Joko, “Analisa Setting Parameter Pemancar TV Digital Dan Pengaruhnya Terhadap Jumlah Isi Siaran Analisa Setting Parameter Pemancar TV Digital Dan Pengaruhnya Terhadap Jumlah Isi Siaran," 2009.

[27] S. Budi, Iswandi, N. Fath, and Y. Pratama, "Pengaruh Lintasan-Jamak terhadap Penerimaan DVB-T2," Conf. Inf. Technol. Electr. Eng., no. November, pp. 355-359, 2015.

[28] W. S. Fadhila, I. Santoso, and A. A. Zahra, "Pengaruh Modulasi M-PSK Pada Unjuk Kerja Sistem Orthogonal Frequency Division Multiplexing (OFDM)," vol. 10, no. 2, pp. 70-76, 2008.

[29] I. Eizmendi et al., "DVB-T2: The second generation of terrestrial digital video broadcasting system," IEEE Trans. Broadcast., vol. 60, no. 2, pp. 258-271, 2014.

[30] Kementrian Komunikasi dan Informatika, "Peraturan Menteri Komunikasi dan Informatika Republik Indonesia Nomor 9 Tahun 2014.” 2014.

[31]W. Rifqi Aji, "Manajemen Bandwidth Untuk Stream Video HD Pada Multiplexer DVBT2 Dengan Metode Statistical Multiplexing," 2018.

[32]ETSI, "ETSI TS 102831 'Digital Video Broadcasting (DVB); Implementation guidelines for a second generation digital terrestrial television broadcasting system (DVB-T2),"” Intellect. Prop., vol. 1, pp. 1-217, 2010.

[33] H. Harada and R. Prasad, "Simulation and Software Radio for Mobile Communications." p. 467, 2002.

[34]N. Ahrens, "Digital Video Broadcasting," no. August. Rohde \& Schwarz, 2015. 